\title{
The Application of Task-based Approach to Oral Business English Teaching
}

\author{
Lv Yixian, Yang Jing
}

Jiangxi Teachers College, Yingtan, Jiangxi, 335000, China

Keywords: Task-based teaching method; Oral business English; vocational education

\begin{abstract}
This paper explores and analyzes the characteristics of the information processing of the teaching method and the effect of improving business English students' oral English ability. Based on the classroom teaching experiment, this paper analyzes the teaching method to improve the oral English ability of vocational college students from the cognitive point of view. It is expected that more English teachers in higher vocational colleges will have a more comprehensive understanding of the task-teaching model and combine them with English classroom teaching to effectively carry out oral business English teaching.
\end{abstract}

\section{Introduction}

With the development of global economic integration, we live in the period of society's rapid development. The rapid development of the economy drives the demand for skilled application talents increasingly and the development of higher vocational education also shows significant momentum. According to Ray's (2015) research, the total number of higher professional education has reached 13.9 million in 2015, of which full-time students remains 10 million or so. According to the requirements of the "Twelfth Five-Year Plan", China's basic tasks are the cultivation, construction, management and service of high-quality and skilled talents of production in the first-line. To achieve this goal, vocational colleges not only need students with basic knowledge and skills, but also need students to go to the first line in work [1].

No matter what the future work the graduates will take, English plays an indispensable role as an essential skill in their job search, promotion and work prospects. Those who have good English communication skills are more likely to gain a foothold in their work. Business English, as the most important communication tool in modern enterprises, have been always sought after by the major colleges and universities. The ultimate goal of language learning is to communicate, and communication is the core of oral language. Oral business English is in line with the requirements of communication and can also better promote students' communication skills. China's accession to the World Trade Organization and the quicker pace of global integration enhance the growing demand for talent with both foreign language skills and business knowledge.

Therefore, oral business English is the prerequisite for cultivating students' international business communication ability [2]. Under the background of English teaching reform in our country, vocational colleges clearly puts forward the teaching idea of "practical purpose and application purpose" in English teaching. The teaching goal of English course is to cultivate students' language application ability. Therefore, the student-centered task-based teaching method gradually steps into the line our sight. Task-based teaching method can fully promote the development of students' language ability, and students have to speak English in the process of completing the task, using English to solve the problem. It changes the past passive acceptance of English knowledge to solve the problem of difficult students. Therefore, the task-based teaching method in the business English oral teaching process is of great significance. 


\section{The Theoretical Basis of Task-based Teaching Method}

\subsection{The Connotation and Characteristics of Oral Business English Course in Universities}

Business English is a specialized use of English in which a business culture group use English as a language medium and business knowledge is the core. It is based on the basic grammar and vocabulary of English with unique linguistic features and linguistic phenomena. It emphasizes the importance of context and situation and is highly professional, covering a wide range of products including product promotion, business dialogue, business Travel, procurement, insurance, complaints and other business-related areas.

Business cooperation is an indispensable communication language, carrying out all aspects of business activities. With the increasing globalization of economic development, China's foreign exchange and cooperation in the fields of economy, culture and education are becoming more and more frequent, and the demand for business English is getting more and more urgent.

\subsection{Current situations of business English oral courses}

The class uses the traditional practice of PPP (presentation, practice, produce) oral teaching mode, according to the order of textbooks. The author explains each topic related to the keywords, expressions and key sentences to the students according to the requirements of the textbook examples to complete the oral practice [3]. Finally students are required to review the content in oral business English after the class. The students are required to continue to practice the topic and give the feedback in the next oral class exercises. The traditional practice of PPP mainly has three steps, which is displayed in Table 1.

Table 1. Traditional practice of PPP mode

\begin{tabular}{|l|l|}
\hline stage & procedures \\
\hline presentation & $\begin{array}{l}\text { Teacher introduces and analyzes the news words, } \\
\text { phrases and sentences about recruitment. Then , he } \\
\text { needs to introduce the knowledge and business points } \\
\text { about recruitment. }\end{array}$ \\
\hline practice & $\begin{array}{l}\text { Under the supervising of teacher, students are required to } \\
\text { do some mechanical oral practice with word , } \\
\text { expressions and sentences in Presentation stage in order } \\
\text { to consolidate the language. }\end{array}$ \\
\hline production & $\begin{array}{l}\text { Teacher requires students to do some language practices } \\
\text { of recruitment with what they have learned. }\end{array}$ \\
\hline
\end{tabular}

\subsection{Task-based teaching and the definition of tasks}

Willis divides the implementation of task-based pedagogy into three steps: pre-task stage (topic and task presentation), task ring phase (task, plan and report) and language focus stage (analysis and practice). Specifically, in the pre-mission phase, the teacher introduces the subject and task, lists the knowledge required to complete the task, describes the requirements of the task and carries out the task.

In task cycle stage, students implement the task of teachers' design and report to the class to completion of the task in the form of individuals, group and other forms. In the language focus phase, there is the analysis where the student analyzes and evaluates other groups' performing in the task and exercises in which students are instructed by the teacher. From the above steps, it can be seen that task-based teaching is the key to the task design [4]. One of the biggest challenges is how to make the difficulty of the task suitable for the learner's current language level. Of course, there are many factors that affect the difficulty of the task, which requires us to design teaching objectives and activities based on the specific circumstances from the student "learning" point of view. So that students continue to gain knowledge and ability in the appropriate difficulty of the task to achieve the best teaching results. 


\subsection{Types and Patterns of Task-based Teaching}

The first type is real task and learning task teaching. Newman believes that the task is a requirement for learners to understand the use of the target language to generate interactive classroom work. Newman creatively divides the task into two categories: one is the "real task" or "the mission" and the other is the "learning task". The real task is close to or similar to the real life of the various tasks. Learning tasks are things that do not normally happen outside the classroom. Most of the tasks belong to the continuum from the learning task to the real task.

The second type is simple tasks and complex tasks teaching. Simple tasks generally have only 1-2 steps, and since the use of language knowledge in learners' getting the information is relatively simple, the relatively simple and specific tasks can be completed in a short period of time. Complex tasks generally have multiple steps tin a number of stages, usually requiring learners to complete the form of a group. It sometimes needs division of labor with access to a variety of information analysis and processing [5]. As a consequence, it takes a long time in involving multiple language knowledge and language skills.

The last is other types task-based teaching. Some researchers divide the task into five categories in an interactive way. Jigsaw refers to each student mastering part of the information and completing a task through the exchange of information. In-formation gap refers to one student mastering the information and another unknown completing the task through the exchange of information from the information master.

\section{Implementation of Task-based Teaching Method in Business Oral English Teaching}

\subsection{Experimental design and teaching procedure}

The experiment is conducted in two multimedia classrooms. The teaching experiment last for eighteen weeks. Teaching experiments are carried out before the teaching experiment and after each oral test. The score of the test is based on the standard of the oral test in "College English Grade $4 \mathrm{El}$ Language Exam". In the experimental group 1 (Task-based group), subjects are required to rewrite the new dialogue around the functional module and the theme of the task. At the same time, subjects in the control group studies the same learning content at the same learning time through traditional teaching methods [6].

The object of this teaching is the vocational students. In general, compared to the comprehensive college students, vocational students speculative ability is relatively weak, but hands-on ability and practical ability is relatively strong. According to the characteristics that vocational students are not good at abstract thinking, teachers need to change abstract things in to the actual life of things so that students are more willing to learn. Therefore, this experiment on the experimental group imposed by the experimental control is mainly "task". For the definition of the task, different researchers hold different views.

Noonan said, "The task is a meaningful classroom activity, including learners understanding, dealing with, outputting or interacting with the target language. Their attention is mainly concentrated in the sense rather than the form. They regard communicative tasks as an activity in foreign language (English) teaching by understanding the activities or behaviors that are performed after the input of the target language or nonverbal information [7]. They think that students use the target language to solve the communication of communication problems in the implementation of the "task". In language communication, students should focus on the expression of meaning rather than language form.

\subsection{Data analysis of the experimental process}

Problem solving refers to the joint efforts of students to solve a task. Decision making requires students to complete a task when they can choose to complete one of the results in a variety of tasks. Exchange of opinions refers to the students to discuss and exchange views. The implementation of the task is very important to the use and development of language. Sheehan proposes that the task 
implementation can be divided into three phases: pre-mission activities, mission activities and post-mission activities (Table 2).

Table 2-1. Independent sample $t$ test (before the experiment)

\begin{tabular}{|c|c|c|c|c|c|}
\hline & \multicolumn{2}{|c|}{$\begin{array}{l}\text { Levene test of } \\
\text { std. equation }\end{array}$} & \multicolumn{3}{|c|}{$\mathrm{t}$ test of mean equation } \\
\hline & $\mathrm{F}$ & Sig & t value & $\mathrm{df}$ & $\begin{array}{l}\text { Sig. } \\
\text { (both) }\end{array}$ \\
\hline \multirow[t]{2}{*}{ grammar(pre-test) } & 4.121 & 0.033 & 0.321 & 60 & 0.82 \\
\hline & & & 0.321 & 58.833 & 0.82 \\
\hline \multirow[t]{2}{*}{ passage(pre-test) } & 0.899 & 0.221 & -0.132 & 60 & 0.793 \\
\hline & & & -0.132 & 57.899 & 0.793 \\
\hline \multirow{2}{*}{$\begin{array}{l}\text { pronunciation(pre-test } \\
\text { ) }\end{array}$} & 0.211 & 0.622 & -0.137 & 60 & 0.43 \\
\hline & & & -0.137 & 58.992 & 0.43 \\
\hline \multirow[t]{2}{*}{ interaction(pre-test) } & 1.727 & 0.191 & 0.111 & 60 & 0.92 \\
\hline & & & 0.111 & 54.874 & 0.92 \\
\hline
\end{tabular}

Table 2-2. Independent sample t test (before the experiment)

\begin{tabular}{|l|l|l|l|l|l|}
\hline & \multicolumn{3}{|l|}{$\begin{array}{l}\text { Levene test of } \\
\text { std. equation }\end{array}$} & \multicolumn{2}{l|}{ t test of mean equation } \\
\hline & F & Sig & t value & df & $\begin{array}{l}\text { Sig.(both } \\
\text { ) }\end{array}$ \\
\hline \multirow{2}{*}{ grammar(after-test) } & 4.628 & 0.037 & 0.360 & 60 & 0.921 \\
\cline { 2 - 6 } & & & 0.360 & 66.069 & 0.921 \\
\hline \multirow{2}{*}{ passage(after-test) } & 1.010 & 0.248 & -0.148 & 60 & 0.891 \\
\cline { 2 - 6 } & & & -0.148 & 65.021 & 0.891 \\
\hline \multirow{2}{*}{$\begin{array}{l}\text { pronunciation(after-test } \\
\text { interaction(after-test) }\end{array}$} & 0.237 & 0.699 & -0.154 & 60 & 0.483 \\
\cline { 2 - 6 } & & & -0.154 & 66.248 & 0.483 \\
\cline { 2 - 6 } & 1.939 & 0.214 & 0.125 & 60 & 1.033 \\
\hline
\end{tabular}

Each stage of the activity has a specific goal. In practice, the pre-mission phase includes introduction, task requirements, and implementation steps. There are many factors that affect the implementation of the task: task difficulty, attention control (time pressure, different language to provide help and unexpected information). Teachers can be adjusted according to the level of students and control. If the task is chosen properly and implemented effectively, it will keep the development of students' language proficiency in a balance of fluency and accuracy.

The "task" evaluation depends on the outcome of the matter. Task - based teaching method is a teaching method with the meaning as the center and the purpose of solving the problem. Students eventually achieve the purpose of skilled use of language in the process of completing the task, that is, in the interaction between teachers and students in the acquisition of language. In short, with the experimental group and the control group using the same teaching materials, the experimental control of the difference is that the task-based teaching method experimental group teaching design is the meaning of the main information processing [8]. The traditional teaching information processing methods are mainly concentrated in the language form rather than the meaning of the form.

\subsection{Comprehensive results based on the experimental data}

The task-based teaching model of higher vocational business English is said to be more successful in oral teaching experiment. This experiment enriches the author's teaching methods and students' learning methods. It not only changes the author's boring business English oral teaching 
methods step-by-step, but also changes the students' rote to cope with oral test learning. According to the main findings, the author has the following teaching inspiration.

Although a teacher is a graduate of English majors, he is still lack of business ethics and oral education in the business theory and practice. The task-based teaching model put forward a very high demand for teachers, who need to learn by their own and play smart to design students in line with the ability. This method is adopted as far in the real language scene as possible, in order to stimulate students to actively build knowledge. However, the lack of business knowledge cannot be designed to meet the real context of the task, and teachers should try a variety of ways to enrich and improve their own business background knowledge. In addition, the theoretical research on the task-based teaching model needs to be further strengthened. Business English teachers have a profound theoretical basis, in order to have a deep understanding of the task-based teaching model. Based on the design of the task of writing and the smooth organization of the entire class teaching activities, oral English teachers should actively participate in a variety of feasible training programs to promote their own theory and practice skills.

Furthermore we should emphasis on emotional teaching and actively create a harmonious business English spoken language atmosphere, which is the biggest feature of the opening environment where students dare to practice to correct their own mistakes. In the first class of business English speaking, teachers can carry out a mobilization and guidance and let it clear in the task-based teaching mode of the classroom. At the same time, the students are the main body of teaching activities with their active participation, and the task can be smooth. In addition, students should be aware of the importance of business English in their future work and life, abandon the idea of dash, and increase the sense of crisis with a positive attitude to learn business English spoken language.

\section{Summary}

The results of research support the view of cognitive linguistics on information processing, that is, the expected test of language output is dependent on the processing of the way in which the information is encoded and the language interaction. The task-based pedagogy, which focuses on semantic processing, can effectively improve the learner's language ability and meanwhile suppress the processing of learners' language forms.

Therefore, in the mandated oral English teaching, the language accuracy and range of students' spoken English are inferior to traditional teaching method. Therefore, we should pay full attention to the students' cognitive psychology in the teaching of business English. We should also pay attention to the fact that the task-based teaching method has positive significance in the application of business English spoken language in higher vocational colleges, viewing the information processing characteristics of task-based teaching. As a teaching method, it is only a part of the complex process of completing the English language learning task. In the oral English teaching, teachers should pay attention to the teaching object and content of differences, combined with the previous teaching in the use of effective teaching methods to achieve the optimization of classroom teaching. The theory of task-based teaching has become a popular foreign language teaching theory in the world, which reveals the social function of language and the goal of foreign language teaching.

\section{References}

[1] Bygate M, Swain M, Skehan P. Researching pedagogic tasks: Second language learning, teaching, and testing[M]. Routledge, 2013.

[2] Yufang F, Xiaoyan T. Application of Task-based Approach in English Language Teaching [J][J]. Foreign Languages and Their Teaching, 2004, 6: 008.

[3] Wenli F. Some Random Remarks on the Task-based Approach in Foreign Language Teaching

[J][J]. Foreign Languages and Their Teaching, 2003, 9: 005.

[4] Richards J C, Rodgers T S. Approaches and methods in language teaching[M]. Cambridge university press, 2014.Xi B. 
[5] The Swot Analysis on the Reserved Talents Training System of Competitive Wushu Routine in Jiangsu Province[J]. Wushu Science, 2013.

[6] Barkhuizen G P. Discovering learners' perceptions of ESL classroom teaching/learning activities in a South African context[J]. TESOL quarterly, 1998: 85-108.

[7] Li T. Affects and Countermeasures of the Implementation of New Rules onCollege Amateur Wushu Training[J]. Wushu Science, 2012.

[8] Ferris D, Tagg T. Academic oral communication needs of EAP learners: What subject - matter instructors actually require[J]. Tesol Quarterly, 1996, 30(1): 31-58. 